\title{
Implications of deforestation for the abundance of restricted-range bird species in a Costa Rican cloud-forest
}

\author{
VICENCIO OOSTRA, LAURENS G. L. GOMES and VINCENT NIJMAN
}

\begin{abstract}
Summary
Central America is a region of great avian diversity, and the highlands of Costa Rica and Panama are particularly rich in endemic bird species. Continuing deforestation has destroyed large parts of the birds' natural habitats in this region. The ability of birds to use non-forest habitats will ultimately determine their vulnerability to further deforestation, and knowledge of their habitat use is therefore essential in planning conservation strategies. We examined the effects of deforestation on the abundance of restricted-range bird species in the southern Costa Rican part of the Talamanca mountain range. We used line-transect distance sampling to obtain densities in forest and non-forest habitats. Most (22/28) restricted-range species were recorded in forest and non-forest. Of 28 restricted-range species, 13 species showed a clear preference for forest and 8 for non-forest, and total numbers were one-and-a-half times higher as high in forest compared with non-forest. Of the 1o most common species, one was more abundant in non-forest and seven were more abundant in forest. We conclude that forest is the primary habitat for the majority of the restricted-range avifauna, and their dependence on forest makes them particularly vulnerable to deforestation. Adequate protection of the forests in these mountains is therefore the best assurance of the long-term survival of these birds.
\end{abstract}

\section{Introduction}

Central America is a region of great avian diversity and contains several centres of bird endemism. The highlands of Costa Rica and Panama have a particularly high diversity of endemic species, and are recognized as an Endemic Bird Area (EBA). An EBA is an area where the distributions of two or more restricted-range bird species, which have a breeding range smaller than 50,000 $\mathrm{km}^{2}$, overlap (BirdLife International 2003, Terborgh and Winter 1983). Ranging from $c$. 1,500 to 3,800 $\mathrm{m}$ a.s.l., the EBA is home to 52 restricted-range species including eight endemic genera (BirdLife International 2003). The occurrence of these mountains as 'islands' of tropical montane cloud-forests (TMCF) and páramo surrounded by different habitats at lower altitudes has probably contributed greatly to this high degree of avian endemism (Fjeldså and Rahbek 2006). As deforestation proceeds, cloud-forests are being converted to open lands, destroying an important habitat of these restricted-range birds (Long 1993). Their ability to use modified (non-forest) habitats will ultimately determine their vulnerability if their natural (forest) habitat is further degraded or destroyed. From a conservation perspective, knowledge on the habitat use of these species is therefore essential. A number of studies have specifically examined habitat use of or effects of deforestation on restricted-range, endemic or threatened species in the Neotropics (Rodriguez-Estrella et al. 1996, Garcia et al. 1998, Creswell et al. 1999, Jacobs and Walker 1999, Welford 2000, Marsden et al. 2001, 2005, Eisermann and Schulz, 2005) and in other tropical regions (Jones et al. 1995, Marsden et al. 1997, Fjeldså 1999, 
Shaw and Shewry 2001, Riley 2002, 2003). Here we examine habitat use of the restricted-range species in the southern Costa Rican part of the Talamanca mountain range. A large part of the Costa Rican and Panama EBA lies within the Talamanca mountain range, which stretches from southern Costa Rica to western Panama and comprises the largest natural forest unit in Central America (UNEP-WCMC 1997). Knowledge on the montane avifauna of southern Costa Rica is mostly restricted to numerous bird checklists of tourist bird-watching sites (e.g. Brak and Vroklage 2002, Anonymous 2003a, b), with only a few scientific studies having been published (Lindell et al. 2004, Sánchez et al. 2004, Wilms and Kappelle 2006). Specifically, quantitative studies on abundance and habitat use are lacking (but see Daily et al. 2001).

The aim of this study is to quantify the effects of deforestation on restricted-range species in the TMCF zone of the Talamanca mountain range. As we focus on species with a very small range, occurring well below the upper treeline on tropical mountains with a recent deforestation history, we hypothesize that most, if not all, restricted-range species under observation will have their highest abundance in forest habitats; these restricted-range species are considered to be 'true' cloud-forest species and may be particularly vulnerable to habitat loss and alteration.

\section{Materials and methods}

\section{Study area}

The study was conducted from December 2003 to April 2004 in the Talamanca mountain range in Costa Rica. Study sites were between $9^{\circ} 32^{\prime}-9^{\circ} 44^{\prime} \mathrm{N}$ and $83^{\circ} 48^{\prime}-83^{\circ} 57^{\prime} \mathrm{W}$, at elevations between 2,200 and $2,600 \mathrm{~m}$ a.s.l. The study area covered approximately $125 \mathrm{~km}^{2}$. The area is (very) humid (rainfall 2,000-3,000 mm annually) with a dry season from December to April. The original vegetation in the area is tropical montane evergreen forest dominated by oak (Quercus), often with a dense understorey. It is bounded by páramo grasslands at c. 3,400 $\mathrm{m}$ a.s.l. and pre-montane forest at c. 1,500 m a.s.l. (Kappelle et al. 1989, Kappelle 1996). Habitat loss and alteration is of recent origin. The Inter-American highway was completed in 1943, crossing the Talamanca mountain range at altitudes up to 3,300 $\mathrm{m}$. Commercial logging and subsequent colonization from the 1950s to the 1970s have left a profound mark on the original vegetation. In the following decades, commercial logging ended and several protected areas were established. Outside the main intact forests are areas where extensive land-use is allowed, and tracts of primary and differentially disturbed forest alternate with secondary forest, pastures and agricultural lands (Kappelle and Juarez 1994, 1995).

\section{Data acquisition}

We used line-transect distance sampling (Buckland et al. 1993) to assess bird densities. Nine transects, each of $2.0 \mathrm{~km}$ in length, were laid out in forest and non-forest habitats. Three transects consisted entirely of primary forest, one transect consisted entirely of grazed pasture and five transects consisted of primary and disturbed forest in a matrix of extensively used agricultural land. Forest was defined as all stretches of continuous forest $>80 \mathrm{~m}$ along the transect line; non-forest was defined as pasture, with remnants of forest $<20 \mathrm{~m}$ along the transect. Transects were laid out in a straight line through the landscape, avoiding human-used paths and roads (Bibby et al. 1992). All transects were surveyed six times (by L.G.L.G. and V.O.), with the exception of two transects that were surveyed four and five times, respectively. Transects were walked at a pace of $1 \mathrm{~km} \mathrm{~h}^{-1}$ and bird surveying was restricted to the period between 06 hoo and o8hoo, with additional observations outside the survey time not used for density estimates. Total effort in forest and non-forest was $49.6 \mathrm{~km}$ and $52.4 \mathrm{~km}$ respectively. All data were collected during fair weather (light winds, no rain). Birds were recorded visually and aurally; birds flying over the transect line were excluded from the analysis. In this paper, the nomenclature of Stiles and Skutch (1989) is used. 


\section{Analysis}

The program Distance (Thomas et al. 2004) was used to estimate bird densities in each habitat separately (cf. Marsden et al. 1997, 2001, 2005, Jacobs and Walker 1999, Cresswell et al. 1999, Shaw and Shewry 2001, Riley 2002, 2003, Marsden and Pilgrim 2003). Detection functions (i.e. the probability of detection of an individual bird as a function of its perpendicular distance to the transect line: Buckland et al. 1993) were computed separately for each bird species for forest and non-forest habitats. Different models with different series expansions were fitted to each histogram. Selection amongst these models was based on Akaike's information criterion (AIC) (Buckland et al. 1993): all selected models proved to have just one parameter included. Variance in density was based on the variance of the fit of the detection function.

For forest and non-forest, densities were estimated separately when $n>30$, provided that the detection function could be calculated accurately, the exception being the Ruddy Treerunner (Margarornis rubiginosus) for which 29 records yielded a reliable detection function. For four species, data were not suitable for modelling a reliable detection function, even though the number of observations was sufficient.

When the density of a species was significantly higher in one habitat type than another, or when the number of records (provided total $n>15$ ) was arbitrarily $>30 \%$ higher in one habitat type compared with the other, we considered this indicative of a preference for this particular habitat type. Within-species density comparisons between forest and non-forest were tested with a Student's t-test (following Buckland et al.'s (1993) specific procedure for density comparisons), and between-species comparisons were tested with a binomial test (Zar 1999). Significance was accepted when $P<0.05$ in a two-tailed test.

\section{Results}

We recorded 35 restricted-range species, 28 of them during the transect walks (Table 1 ). The 10 species for which we were able to calculate densities in both forest and non-forest can be considered as the most common restricted-range species in the study area. Eight of these species were significantly more abundant in one habitat compared with the other $(t$-test, $P<0.005)$ and this was considered as a preference for that habitat (Table I, Figure 1). Significantly more common restricted-range species showed a preference for forest than for non-forest (Binomial test, $n=8, x=1, P=0.04$ ) and their total density was twice as high in forest compared with non-forest. Considering all restricted-range species, almost twice as many species showed a preference for forest compared with non-forest, the difference, however, not being significant (Binomial test, $n=21, x=8, P=0.19$ ).

The differences in abundance between forest and non-forest varied greatly among species. The Long-tailed Silky-flycatcher (Ptilogonys caudatus) was about 7 times more abundant in nonforest, and although the small number of observations did not allow its density to be estimated in forest, the Volcano Hummingbird (Selasphorus flammula) showed a similar difference in abundance. Conversely, the Collared Redstart (Myioborus torquatus) and the Ruddy Treerunner were about 4 times more abundant in forest compared with non-forest. Likewise, the Blackcheeked Warbler (Basileuterus melanogenys) showed a clear preference for forest. Six additional species were recorded in only one habitat type: differences in their habitat use may be even more extreme, but generally the number of observations was low, precluding any straightforward conclusions. The notable exception might be the Black Guan (Chamaepetes unicolor), a species that was regularly recorded in, but never outside, forest.

\section{Discussion}

This is the first study to present density estimates of restricted-range birds in the Talamanca mountain range TMCF zone, and indeed one of the few studies to present quantitative 
Table 1 . Abundance of 28 restricted-range species in forest and non-forest habitats, Talamanca mountain range, Costa Rica.

\begin{tabular}{|c|c|c|c|c|c|}
\hline Species & $\begin{array}{l}\text { No. of } \\
\text { observations } \\
\text { in forest }\end{array}$ & $\begin{array}{l}\text { No. of } \\
\text { observations } \\
\text { in } \\
\text { non-forest }\end{array}$ & $\begin{array}{l}\text { Density } \\
\text { in forest } \\
\text { (ind. } \mathrm{km}^{-2} \text { ) } \\
\pm \mathrm{SD}\end{array}$ & $\begin{array}{l}\text { Density } \\
\text { in non-forest } \\
\text { (ind. km }{ }^{-2} \text { ) } \\
\pm \mathrm{SD}\end{array}$ & $\begin{array}{l}\text { Habitat } \\
\text { use }\end{array}$ \\
\hline $\begin{array}{l}\text { Sooty-capped Bush-Tanager } \\
\text { Chlorospingus pileatus }\end{array}$ & 319 & 158 & $317 \pm 16$ & $141 \pm 9$ & $\mathrm{~F}$ \\
\hline $\begin{array}{l}\text { Black-billed Nightingale-Thrush } \\
\text { Catharus gracilirostris }\end{array}$ & 264 & 167 & $54 \pm 3$ & $35 \pm 2$ & $\mathrm{~F}$ \\
\hline $\begin{array}{l}\text { Long-tailed Silky-flycatcher } \\
\text { Ptilogonys caudatus }\end{array}$ & 36 & 265 & $8 \pm 1$ & $56 \pm 3$ & NF \\
\hline $\begin{array}{l}\text { Golden-browed Chlorophonia } \\
\text { Chlorophonia callophrys }\end{array}$ & 155 & 103 & $36 \pm 3$ & $17 \pm 1$ & $\mathrm{~F}$ \\
\hline $\begin{array}{l}\text { Black-faced Solitaire Myadestes } \\
\text { melanops }\end{array}$ & 206 & 12 & - & - & $\mathrm{F}$ \\
\hline $\begin{array}{l}\text { Ochraceous Wren Troglodytes } \\
\text { ochraceus }\end{array}$ & 136 & 63 & $59 \pm 4$ & $45 \pm 4$ & - \\
\hline $\begin{array}{l}\text { Fiery-throated Hummingbird } \\
\text { Panterpe insignis }\end{array}$ & 128 & 67 & $119 \pm 14$ & $50 \pm 2$ & $\mathrm{~F}$ \\
\hline $\begin{array}{l}\text { Yellow-thighed Finch Pselliophorus } \\
\text { tibialis }\end{array}$ & 106 & 71 & $128 \pm 10$ & $59 \pm 4$ & $\mathrm{~F}$ \\
\hline $\begin{array}{l}\text { Collared Redstart Myioborus } \\
\text { torquatus }\end{array}$ & 128 & 34 & $117 \pm 9$ & $26 \pm 3$ & $\mathrm{~F}$ \\
\hline $\begin{array}{l}\text { Ruddy Treerunner Margarornis } \\
\text { rubiginosus }\end{array}$ & 104 & 29 & $102 \pm 11$ & $24 \pm 2$ & $\mathrm{~F}$ \\
\hline $\begin{array}{l}\text { Flame-throated Warbler Parula } \\
\text { gutturalis }\end{array}$ & 52 & 50 & $50 \pm 6$ & $46 \pm 5$ & - \\
\hline $\begin{array}{l}\text { Volcano Hummingbird Selasphorus } \\
\text { flammula }\end{array}$ & 8 & 62 & - & $84 \pm 6$ & NF \\
\hline $\begin{array}{l}\text { Black-cheeked Warbler Basileuterus } \\
\text { melanogenys }\end{array}$ & 55 & 5 & $78 \pm 13$ & - & $\mathrm{F}$ \\
\hline Yellow-winged Vireo Vireo carmioli & 31 & 23 & $32 \pm 4$ & - & $\mathrm{F}$ \\
\hline $\begin{array}{l}\text { Prong-billed Barbet Semnornis } \\
\text { frantzii }\end{array}$ & 22 & 36 & & & NF \\
\hline $\begin{array}{l}\text { Sulfur-winged Parakeet Pyrrhura } \\
\text { hoffmanni }\end{array}$ & 11 & 46 & & & NF \\
\hline $\begin{array}{l}\text { Large-footed Finch Pezopetes } \\
\text { capitalis }\end{array}$ & 28 & 18 & & & $\mathrm{~F}$ \\
\hline $\begin{array}{l}\text { Black-capped Flycatcher Empidonax } \\
\text { atriceps }\end{array}$ & 14 & 30 & & & NF \\
\hline $\begin{array}{l}\text { Spangled-cheeked Tanager Tangara } \\
\text { dowii }\end{array}$ & 9 & 25 & & & NF \\
\hline $\begin{array}{l}\text { Black-and-yellow Silky-flycatcher } \\
\text { Phainoptila melanoxantha }\end{array}$ & 11 & 17 & & & NF \\
\hline $\begin{array}{l}\text { Streaked-breasted Treehunter } \\
\text { Thripadectes rufobrunneus }\end{array}$ & 18 & 3 & & & $\mathrm{~F}$ \\
\hline Slaty Flowerpiercer Diglossa plumbea & 4 & 17 & & & NF \\
\hline Black Guan Chamaepetes unicolor & 17 & o & & & $\mathrm{F}$ \\
\hline $\begin{array}{l}\text { Silvery-throated Jay Cyanolyca } \\
\text { argentigula }\end{array}$ & 7 & o & & & - \\
\hline $\begin{array}{l}\text { Ochraceous Pewee Contopus } \\
\text { ochraceus }\end{array}$ & 2 & o & & & - \\
\hline Zeledonia Zeledonia coronata & 2 & o & & & _ \\
\hline
\end{tabular}


Table 1. Continued.

\begin{tabular}{|c|c|c|c|c|c|}
\hline Species & $\begin{array}{l}\text { No. of } \\
\text { observations } \\
\text { in forest }\end{array}$ & $\begin{array}{l}\text { No. of } \\
\text { observations } \\
\text { in } \\
\text { non-forest }\end{array}$ & $\begin{array}{l}\text { Density } \\
\text { in forest } \\
\text { (ind. } \mathrm{km}^{-2} \text { ) } \\
\pm \mathrm{SD}\end{array}$ & $\begin{array}{l}\text { Density } \\
\text { in non-forest } \\
\text { (ind. } \mathrm{km}^{-2} \text { ) } \\
\pm \mathrm{SD}\end{array}$ & $\begin{array}{l}\text { Habitat } \\
\text { use }\end{array}$ \\
\hline $\begin{array}{l}\text { Bare-shanked Screech-Owl Otus } \\
\text { clarkii }\end{array}$ & 1 & o & & & - \\
\hline Sooty Robin Turdus nigrescens & $\mathrm{o}$ & 1 & & & - \\
\hline
\end{tabular}

For forest and non-forest separately, densities were calculated when $n>30$ and provided that the detection curve could be estimated reliably (see text for details).

$\mathrm{F}$, significantly higher density or more than $30 \%$ more frequently observed in forest; NF, significantly higher density or more than $30 \%$ more frequently observed in non-forest (see text for details).

Restricted-range species recorded in the study area but not during the transect walks: Black-thighed Grosbeak (Pheucticus tibialis), Dark Pewee (Contopus lugubris), Golden-bellied Flycatcher (Myiodynastes hemichrysus), Peg-billed Finch (Acanthidops bairdii), Red-fronted Parrotlet (Touit costaricensis), Silveryfronted Tapaculo (Scytalopus argentifrons), White-tailed Emerald (Elvira chionura).

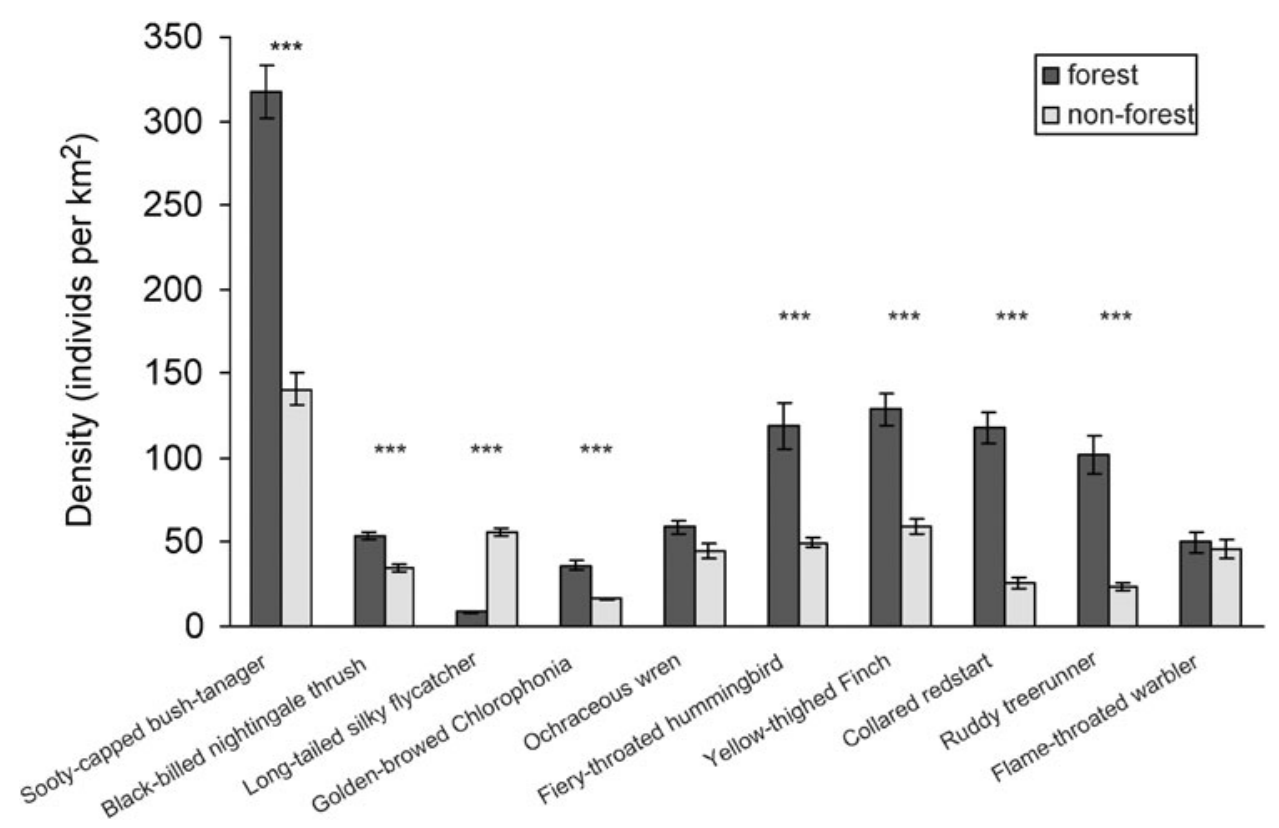

Figure 1 . Densities of the 10 most common restricted-range species in forest and non-forest habitats, Talamanca mountain range, Costa Rica. Differences in density between forest and nonforest were tested with Student's $t$-test for each species separately, significant differences being indicated by asterisks $\left({ }^{* *} \mathrm{P}<0.005\right)$.

abundance data on Central American mountain birds. We found that most species are more common in forest than in non-forest. Of the most common species (those for which densities could be obtained), only one was most abundant in non-forest, and the total density of these common birds was twice as high in forest compared with non-forest. As most restricted-range species showed a preference for forest we conclude that forest is the primary habitat for the majority of the restricted-range avifauna present in the area. 
Considering only studies using distance sampling and standardizing all result by averaging densities across the two most common restricted-range species sampled, we compared our estimate of bird densities in forest habitat with density estimates from Ecuadorian (Cresswell et al. 1999, Jacobs and Walker 1999) and Brazilian (Marsden et al. 2001) primary forests. Mean density in forest in our study area $\left(223\right.$ ind. $\mathrm{km}^{-2}$ ) was considerable higher than in north-eastern Ecuador (55 ind. $\mathrm{km}^{-2}$; Cresswell et al. 1999), southern Ecuador (53 ind. $\mathrm{km}^{-2}$; Jacobs and Walker 1999) and Brazil (41 ind. $\mathrm{km}^{-2}$; Marsden et al. 2001). Unfortunately, we could not compare the results from our study with other studies in Costa Rica, as density estimates based on distance sampling were not available for Costa Rican birds.

In our study, the Volcano Hummingbird and the Long-tailed Silky-flycatcher had higher abundances in non-forest than in forest. Stotz et al. (1996), who compiled a database on Neotropical birds and categorized their primary habitat and their degree of tolerance to disturbance, report the first species to have páramo grasslands as its primary habitat, which may explain its preference for open, non-forest habitat at lower altitudes. This suggests that this species may have extended its range after deforestation, descending from mountain-top páramo into deforested areas at lower elevations. The Long-tailed Silky-flycatcher's reported elevational limit is well below treeline (Stotz et al. 1996), and hence the higher abundance of this species in deforested areas cannot be explained by the same mechanism. Stotz et al. (1996) described the Long-tailed Silky-flycatcher as occurring commonly in primary and secondary montane forest and having low sensitivity to disturbance, and Skutch (1965) observed it only in pastures. Conversely, Barrantes and Pereira (2002) found this species to have moderate affinity with forest and Lindell et al. (2004) found it to be a forest specialist. Although there may be an effect of geographic location, elevation or season on habitat usage, the cause of these disparate findings among studies remains unclear. Any conclusions regarding the resilience of the Long-tailed Silky-flycatcher to human disturbance must be met with caution.

Using fixed-radius point counts, Daily et al. (2001) reported numbers of birds in southern Costa Rica, including the Ochraceous Wren (Troglodytes ochraceus) and the Golden-browed Chlorophonia (Chlorophonia callophrys) that were also censused in our study. In Daily et al.'s (2001) study none of these species occurred in open habitats, whereas in our study both occurred in high densities outside forest. Most of the species we found to be more common in forest were categorized by Stotz et al. (1996) as being moderately or highly sensitive to disturbance. The exception was the Black-billed Nightingale-Thrush (Catharus gracilirostris), considered by Stotz et al. (1996) to have a low sensitivity to disturbance, whereas we found it to be more than $1^{1 / 2}$ times more abundant in forest than in non-forest. Similarly, most of the species we found to be more common in non-forest were categorized by Stotz et al. (1996) as having either a moderate or a low sensitivity to disturbance. An exception could be the Spangled-cheeked Tanager (Tangara dowii) (considered by Stotz et al. (1996) to be highly sensitive to disturbance) that we found to be more abundant in non-forest. In northern Costa Rica, Barrantes and Pereira (2002) reported the Golden-browed Chlorophonia to have moderate, and the Black-faced Solitaire (Myadestes melanops) to have high affinity with forest. This was in accordance with our study. Finally, the Near-Threatened Black Guan was reported to be a forest specialist (Lindell et al. 2004) and to have high sensitivity to disturbance (Stotz et al. 1996), which is also in accordance with our result for this species.

In summary, the limited number of studies that include species that were also censused in our study support the more general conclusion that forest is the primary habitat for the majority of these restricted-range bird species.

By definition, the species in this study have a small range, most species even smaller than $15,000 \mathrm{~km}^{2}$ (BirdLife International 2003), and they have their centre of abundance at middle to high elevations (Stotz et al. 1996). As the study area was originally completely covered by forest and deforestation is quite recent (Kappelle 1996), the highland pastures that comprise most of the deforested areas are essentially a new habitat that did not occur previously in this area. Throughout the mountain range, páramo vegetation is present in smaller or larger patches. Our 
study area was well below the treeline and the nearest large páramo is situated at $>30 \mathrm{~km}$. Therefore we expected that bird species confined to these mountains occurred primarily in forest, the most common habitat prior to human intervention. The majority of the restricted-range bird community in our study indeed showed a preference for forest, confirming our expectations.

Nevertheless, most species that had their highest abundance in forest occurred in non-forest as well, albeit in lower numbers, and few species occurred exclusively in forest. This can be attributed to the occurrence of small patches of degraded forest and remnant trees in the nonforest habitat, and to the relative proximity of large forest tracks. Studies from other areas in Costa Rica indeed suggest that the countryside can still harbour moderately high levels of avian diversity (Daily et al. 2001, Hughes et al. 2002, Matlock et al. 2002). Alternatively, the deforestation is so recent that the avifaunal community has probably not yet fully responded to these changes and the declines in density observed today might be a first sign of further declines, ultimately resulting in local extinctions, as documented for other Neotropical mountain areas (e.g. Kattan et al. 1992). Species that have forest as their primary habitat will undoubtedly decline in numbers if deforestation proceeds, especially those recorded in low numbers in forest only.

In Costa Rica, the remaining highland forest is generally well protected, but not so in Panama (BirdLife International 2003). Our study confirms and quantifies the notion that most of the restricted-range species are forest-dependent and consequently particularly vulnerable to deforestation. Continued active protection of these forests in Costa Rica, and expansion of the protected area network in Panama, are therefore essential for the long-term survival of this group of birds.

\section{Acknowledgements}

We thank Prof. Dr A. M. Cleef (IBED, University of Amsterdam) and Dr M. Kappelle (The Nature Conservancy, San José) for help and support. Dr J. G. B. Oostermeijer (IBED, University of Amsterdam) and two anonymous reviewers commented on the manuscript. Financial support for the fieldwork was provided by Alberta Mennega Stichting, Amsterdamse Universiteits Vereniging, Bekker-la Bastide-Fonds, Dr Hendrik Muller's Vaderlandsch Fonds and Schuurman Schimmel-van Outeren Stichting.

\section{References}

Anonymous (2003a) Genesis II Cloudforest Preserve checklist of birds. Cartago, Costa Rica: El Cañon del Guarco.

Anonymous (2003b) Savegre Mountain Hotel checklist of birds. San José, Costa Rica: San Gerardo de Dota.

Barrantes, G. and Pereira, A. (2002) Seed dissemination by frugivorous birds from forest fragments to adjacent pastures on the western slope of Volcán Barva, Costa Rica. Rev. Biol. Trop. 50: 569-575.

Bibby, C. J., Burgess, N. D. and Hill, D. A. (1992) Bird census techniques. London: Academic Press.

BirdLife International (2003) BirdLife's online world bird database: the site for bird conservation. Cambridge, U.K.: BirdLife International [http://www. birdlife.org, accessed 26 February 2006].

Brak, B. and Vroklage, M. (2002) Birds observed at La Chonta. Appendix to Brak, B. and Vroklage, M. The vegetation of la Chonta peat bog, Talamanca mountain range, Costa Rica. Internal report, Wageningen University, The Netherlands. Buckland, S. T., Anderson, D. R., Burnham, K. P. and Laake, J. L. (1993) Distance sampling: estimating abundance of biological populations. London: Chapman \& Hall.

Cresswell, W., Hughes, M., Mellanby, R., Bright, S., Catry, P., Chaves, J., Freile, J., 
Gabela, A., Martineau, H., Macleod, R., McPhie, F., Anderson, N., Holt, S., Barabas, S., Chapel, C. and Sánchez, T. (1999) Densities and habitat preferences of Andean cloud-forest birds in pristine and degraded habitats in north-eastern Ecuador. Bird Conserv. Int. 9: 129-145.

Daily, G. C., Ehrlich, P. R. and SánchezAzofeifa, G. A. (2001) Countryside biogeography: use of human-dominated habitats by the avifauna of southern Costa Rica. Ecol. Appl. 11: 1-13.

Eisermann, K. and Schulz, U. (2005) Birds of a high-altitude cloud forest in Alta Verapaz, Guatemala. Rev. Biol. Trop. 53: 577-594.

Fjeldså, J. (1999) The impact of forest disturbance on the endemic avifauna of the Udzungwa Mountains, Tanzania. Bird Conserv. Int. 9: 47-62.

Fjeldså, J. and Rahbek, C. (2006) Diversification of Tanagers, a species rich bird group, from lowlands to montane regions of South America. Integ. Comp. Biol. 46: 72-81.

Garcia, S., Finch, D. M. and Chávez León, G. (1998) Patterns of forest use and endemism in resident bird communities of northcentral Michoacán, Mexico. Forest Ecol. Manage. 110: 151-171.

Hughes, J. B., Daily, G. C. and Ehrlich, P. R. (2002) Conservation of tropical birds in countryside habitats. Ecol. Lett. 5: 121-129.

Jacobs, M. D. and Walker, J. S. (1999) Density estimates of birds inhabiting fragments of cloud forest in southern Ecuador. Bird Conserv. Int. 9: 73-79.

Jones, M. J., Linsley, M. D. and Marsden, S. J. (1995) Population sizes, status and habitat associations of the restricted-range bird species of Sumba, Indonesia. Bird Conserv. Int. 5: 21-52.

Kappelle, M. (1996) Los bosques de roble (Quercus) de la Cordillera de Talamanca, Costa Rica: biodiversidad, ecología, conservación y desarrollo., Heredia, Costa Rica: University of Amsterdam/Instituto Nacional de Biodiversidad.

Kappelle, M. and Juárez, M. E. (1994) The Los Santos Forest Reserve: a buffer zone vital for the Costa Rican La Amistad Biosphere Reserve. Environm. Conserv. 21: 166-169.
Kappelle, M. and Juárez, M. E. (1995) Agroecological zonation along an altitudinal gradient in the montane belt of the Los Santos Forest Reserve in Costa Rica. Mountain Res. Dev. 15: 19-37.

Kappelle, M., Cleef, A. M. and Chaverri, A. (1989) Phytosociology of montane Chusquea-Quercus forests, Cordillera de Talamanca, Costa Rica. Brenesia 32: 73-105.

Kattan, G. H., Alvarez-López, H. and Giraldo, M. (1992) Forest fragmentation and bird extinctions: San Antonio eighty years later. Conserv. Biol. 8(1): 138-146.

Lindell, C. A., Chomentowski, W. H. and Zook, J. R. (2004) Characteristics of bird species using forest and agricultural land covers in southern Costa Rica. Biodiv. Conserv. 13: 2419-2441.

Long, A. J. (1993) The importance of tropical montane cloud forests for endemic and threatened birds. Pp. 79-106 in L. S. Hamilton, J. O. Juvik and F. Scatena, eds. Tropical mountain cloud forests. Ecological Studies Series, Volume ı10. Berlin: Springer.

Marsden, S. J. and Pilgrim, J. D. (2003) Factors influencing the abundance of parrots and hornbills in pristine and disturbed forests on New Britain, PNG. Ibis 145: $45-53$.

Marsden, S. J., Jones, M. J., Linsley, M. D., Mead, C. and Hounsome, M. V. (1997) The conservation status of the restricted-range lowland birds of Buru, Indonesia. Bird Conserv. Int. 7: 213-233.

Marsden, S. J., Whiffin, M. and Galetti, M. (2001) Bird diversity and abundance in forest fragments and Eucalyptus plantations around an Atlantic forest reserve, Brazil. Biodiv. Conserv. 10: 737-751.

Marsden, S. J., Whiffin, M., Galetti, M. and Fielding, A. H. (2005) How well will Brazil's system of Atlantic forest reserves maintain viable bird populations? Biodiv. Conserv. 14: 2835-2853.

Matlock Jr, R. B., Rogers, D., Edwards, P. J. and Martin, S. G. (2002) Avian communities in forest fragments and reforestation areas associated with banana plantations in Costa Rica. Agric. Ecosyst. Environm. 91: 199-215. 
Riley, J. (2002) Population sizes and the status of endemic and restricted-range bird species on Sangihe Island, Indonesia. Bird Conserv. Int. 12: 53-78.

Riley, J. (2003) Population sizes and the conservation status of endemic and restricted-range bird species on Karakelang, Talaud Islands, Indonesia. Bird Conserv. Int. 13: 59-74.

Rodriguez-Estrella, R., de la Luz, J. L. L., Breceda, A., Castellanos, A., Cancino, J. and Llinas, J. (1996) Status, density and habitat relationships of the endemic terrestrial birds of Socorro island, Revillagigedo islands, Mexico. Biol. Conserv. 76: 195-202.

Sánchez, J. E., Barrantes, G. and Duran, F. (2004) Distribución, ecología y conservación de la avifauna de la cuenca del río Savegre, Costa Rica. Brenesia 61: 63-93.

Shaw, P. and Shewry, M. (2001) Population density and habitat associations of restricted-range bird species at Ruhija, Bwindi Impenetrable Forest, Uganda. Bird Conserv. Int. 11: 161-174.

Skutch, A. F. (1965) Life history of the Longtailed Silky-flycatcher, with notes on related species. Auk 82: 375-426.

Stiles, F. G. and Skutch, A. F. (1989) A guide to the birds of Costa Rica. London: Christopher Helm.

Stotz, D. F., Fitzpatrick, J. W., Parker, T. A. and Moskovits, D. K. (1996) Neotropical birds: ecology and conservation. Chicago: University of Chicago Press.
Terborgh, J. and Winter, B. (1983) A method for siting parks and reserves with special reference to Colombia and Ecuador. Biol. Conserv. 27: 45-58.

Thomas, L., Laake, J. L., Strindberg, S., Marques, F. F. C., Buckland, S. T., Borchers, D. L., Anderson, D. R., Burnham, K. P., Hedley, S. L., Pollard, J. H. and Bishop, J. R. B. (2004) Distance 4.1. Release 2. Research Unit for Wildlife Population Assessment, University of St Andrews, U.K. [http://www.ruwpa. st-and.ac.uk/distance/].

UNEP-WCMC (1997) Protected Areas Programme, UNEP World Conservation Monitoring Centre, Cambridge, U.K. [http://www.wcmc.org.uk/protected_areas/ data/wh/talamanc.html, accessed 26 February 2006].

Welford, M. R. (2000) The importance of early successional habitats to rare, restricted-range, and endangered birds in the Ecuadorian Andes. Bird Conserv. Int. 10: $351-359$.

Wilms, J. J. A. M. and Kappelle, M. (2006) Frugivorous birds, habitat preference and seed dispersal in a fragmented Costa Rican montane oak forest landscape. Pp. 309-324 in M. Kappelle, ed. Ecology and conservation of Neotropical montane oak forests. Ecological Studies Series, Volume 185. Berlin: Springer.

Zar, J. H. (1999) Biostatistical analysis. New Jersey: Prentice-Hall.

\section{VICENCIO OOSTRA}

Leiden University, Van der Klaauw Laboratory, Kaiserstraat 63, 2311 GP Leiden, The Netherlands.

LAURENS G. L. GOMES, VINCENT NIJMAN

University of Amsterdam, Zoological Museum, P. O. Box 94766, 1090 GT Amsterdam, The Netherlands.

\section{VINCENT NIJMAN*}

Oxford Brookes University, School of Social Sciences and Law, Department of Anthropology and Geography, OX 3 oBP Oxford, UK.

*Author for correspondence; e-mail:Vnijman@brookes.ac.uk 